\title{
PENGARUH PEMANASAN DAN ASAL EKSPLAN PADA PERTUMBUHAN DAN PERKEMBANGAN BAWANG MERAH (Allium ascolonicum L.)
}

\author{
The Effect Heat Treatment and Explants Source on Proliferation of Shallots \\ (Allium ascolonicum L)
}

\author{
Asih K. Karjadi* dan Neni Gunaeni \\ Balai Penelitian Tanaman Sayuran \\ Jl. Tangkuban Perahu no. 517 Lembang- Bandung Barat \\ *Alamat Korespondensi: asihkk@yahoo.com
}

\begin{abstract}
ABSTRAK
Tanaman bawang merah (Allium ascolonicum L) termasuk dalam genus Allium sp yang diperbanyak secara vegetatif melalui umbi. Perbanyakan benih bawang sudah dilakukan secara in vitro (konvensional), untuk tujuan peningkatan mutu atau hanya perbanyakan tanaman . Penelitian dilaksanakan di Laboratorium Kultur Jaringan Balai Penelitian Tanaman Sayuran, pada bulan Februari sampai Agustus 2014. Untuk menghasilkan tanaman bebas penyakit terutama virus dapat digunakan teknik kultur jaringan yang dikombinasikan dengan perlakuan pemanasan. Penelitian bertujuan untuk melihat pengaruh pemanasan dan sumber eksplan terhadap pertumbuhan dan perkembangan eksplan bawang merah.. Perlakuan pemanasan bahan eksplan bawang merah dilakukan secara bertahap selama 4 minggu, masing-masing 1 minggu untuk suhu $\left(30,33,35\right.$ dan $\left.37^{\circ} \mathrm{C}\right)$. Media yang dipergunakan untuk penumbuhan eksplan adalah $\mathrm{MS}+\mathrm{MS}$ vits + sucrose $30 \mathrm{~g} / 1+\mathrm{IAA} 2 \mathrm{mg} / \mathrm{l}+\mathrm{Kinetin} 2 \mathrm{mg} / \mathrm{l}+\mathrm{GA} 30.01$ $\mathrm{mg} / \mathrm{l}$ agar gelgro $2 \mathrm{~g} / \mathrm{l} \mathrm{pH} \mathrm{5.7}$. Penelitian terdiri dari 2 kegiatan yaitu Perlakuan pada cv. Pikatan, dan pada cv. Bima Brebes. Sebagai eksplan dipergunakan yaitu (1/3 bulb/ umbi) dan (shoot tip/ jaringan meristematik dengan beberapa daun primordia). Perlakuan eksplan yang digunakan yaitu tanpa pemanasan dan dengan pemanasan. Pertumbuhan dan perkembangan dari planlet diamati pada penelitian ini. Hasil dari penelitian menunjukkan bahwa perlakuan pemanasan bahan eksplan bawang merah cv. Bima Brebes, belum menurunkan persentase planlet yang terinfeksi virus. Eksplan (1/3 bulb) dan (shoot tip), mempunyai pertumbuhan eksplan diatas 50\%. Umumnya semakin kecil eksplan persentase planlet abnormal semakin tinggi. Kontaminasi kultur umumnya disebabkan bakteri dan jamur yang terbawa dari eksplan (endogen). Perlakuan pemanasan bahan eksplan bawang merah secara visual tidak berpengaruh pada persentase pertumbuhan dan persentase kultur terkontaminasi.
\end{abstract}

Kata kunci: Bawang merah, Allium ascolonicum L, pemanasan, asal eksplan

\section{ABSTRACT}

Red onion plants (Allium ascolonicum L) are included in the genus Allium sp which is propagated vegetatively through tubers. Propagation of onion seeds has been done in vitro (conventionally), for the purpose of quality improvement or only plant propagation. The research was carried out at the Tissue Culture Laboratory, Balai Penelitian Tanaman Sayuran (Balitsa) from February to August 2014. To produce plants free of mainly viral diseases can be used tissue culture techniques combined with heating treatment. Research aims were to look at the effect of heating and explants on the growth and development of red onion explants. The treatment of the onion explants was heated gradually for 4 weeks, 1 week each for temperatures (30, 33, 35 and $\left.37^{\circ} \mathrm{C}\right)$. The media used for the growth of explants is MS +MS vits + sucrose $30 \mathrm{~g} / \mathrm{l}+\mathrm{IAA} 2 \mathrm{mg} / \mathrm{l}+$ Kinetin $2 \mathrm{mg} / \mathrm{l}+\mathrm{GA3} 0.01 \mathrm{mg} / \mathrm{l}$ so that gelgro $2 \mathrm{~g} / \mathrm{l} \mathrm{pH}$ 5.7. The study consisted of 2 activities, namely, treatment at $\mathrm{cv}$. Pikatan, and at cv. Bima Brebes. As explants it is used (1/3 bulb / tuber) and (shoot tip / meristematic tissue with several leaves of primordia). The explants treatment used are without heating and by heating. Growth and development of plantlets was observed in this study. The results showed that the heating treatment of explants onions cv. Bima Brebes, has not reduced the percentage of plantlets infected with the virus. Explants (1/3 bulb) and (Shoot tip), have explants growth above 50\%. Generally the smaller explants the higher percentage of abnormal plantlets. Culture contamination is generally caused by bacteria and fungi that are carried away from explants (endogenous). The treatment of heating the onion explants material visually had no effect on the percentage of growth and percentage of contaminated culture.

Keywords: red onion, Allium ascolonicum L, heating treatment, source of explant 


\section{PENDAHULUAN}

Tanaman bawang merah (Allium ascolonicum L) termasuk dalam genus Alliums sp yang diperbanyak secara vegetative melalui umbi. Di Negara-negara maju perbenihan bawang sudah dilakukan secara in vitro/mikropropagasi atau inkonvensional baik untuk tujuan peningkatan mutu atau perbanyakan tanaman (Abo-El Nil, 1977; Kamstaityte and Stanys, 2004)

Pada tanaman yang diperbanyak secara vegetatif, penyakit virus merupakan penyakit penting yang perlu dipecahkan. Virus yang sudah menginfeksi akan terus berkembang secara turun temurun. Menurut hasil penelitian Walkey dkk. (1987) serta Kurniawan dan Suastika (2013), infeksi virus dapat mengurangi produksi antara 25 $-50 \%$ jumlah siung, dan bobot umbi dapat tereduksi sampai $45 \%$. Untuk tanaman bawang merah, salah satu cara mengeliminasi penyakit virus dengan pelakuan pemanasan, kultur meristem (kultur jaringan), penggunaan antiviral Ribavirin atau kombinasi dari beberapa perlakuan. Kombinasi teknik ini dapat meningkatkan kualitas dan kuantitas benih yang dihasilkan.

Teknik kultur jaringan tanaman adalah suatu teknik penumbuhan bagian tanaman berupa potongan jaringan atau organ tanaman yang dipisahkan dari lingkungan alami dalam suatu media buatan secara aseptik. Prinsip dasar dalam kultur jaringan adalah sel merupakan bagian unit biologis terkecil yang dapat melakukan aktifitas hidup, reproduksi dan tumbuh menjadi tanaman sempurna (Ayabe and Sumi, 1998; Abo-El Nil, 1977). Media tumbuh yang dipergunakan pada teknik kultur jaringan terdiri dari makro, mikro elemen, asam amino, vitamin dan suplemen organik lainnya seperti sumber karbohidrat, zat pengatur tumbuh (Seif et al., 2011). Perbanyakan bawang merah dengan menggunakan teknik kultur jaringan dipengaruhi oleh beberapa faktor yaitu komposisi media tumbuh, genotype, asal eksplan /donor eksplan (Buitteveld and Molenaarm, 1994; Eady et al., 1998; Zheng et al., 1998).

Penelitian bertujuan untuk melihat pengaruh pemanasan dan sumber eksplan terhadap pertumbuhan dan perkembangan eksplan bawang merah. Dari penelitian ini diharapkan dapat menghasilkan tanaman bebas penyakit terutama virus dengan menggunakan teknik kultur jaringan yang dikombinasikan dengan perlakuan pemanasan bahan eksplan. .

\section{METODE}

Penelitian dilaksanakan di Laboratorium Kultur Jaringan, Balai Penelitian Tanaman Sayuran pada bulan Februari sampai dengan Agustus 2014. Sebagai bahan eksplan dipergunakan umbi 
bawang merah terinfeksi virus (berdasarkan hasil uji serologi DAS ELISA) yaitu cv. Pikatan dan cv. Bima Brebes. Perlakuan pemanasan umbi dilaksanakan secara bertahap selama 4 minggu yaitu pemanasan $30{ }^{\circ} \mathrm{C}$ selama 1 minggu, $33{ }^{\circ} \mathrm{C}$ selama 1 minggu, $35^{\circ} \mathrm{C}$ selama 1 minggu dan 37 ${ }^{\circ} \mathrm{C}$ selama 1 minggu .

Pelaksanaan penelitian terdiri atas 2 kegiatan. Kegiatan pertama yaitu perlakuan pada cv. Pikatan, dengan media yang dipergunakan untuk penumbuhan eksplan adalah MS (1962) + MS vits + sukrose 30 $\mathrm{g} / 1+\mathrm{IAA} 2 \mathrm{mg} / 1+$ Kinetin $2 \mathrm{mg} / 1+\mathrm{GA}_{3}$ $0.01 \mathrm{mg} / 1$ agar gelgro $2 \mathrm{~g} / \mathrm{l} \mathrm{pH} \quad$ 5.7. Sedangkan eksplan digunakan 1/3 bulb/ umbi (A) dan shoot tip/ jaringan meristematik dengan beberapa daun primordia (B).

Kegiatan kedua yaitu perlakuan pada cv. Bima Brebes. Media yang digunakan untuk penumbuhan eksplan : MS (1962) + MS vits + sukrose $30 \mathrm{~g} / 1+$ IAA $2 \mathrm{mg} / 1+$ Kinetin $2 \mathrm{mg} / \mathrm{l}+\mathrm{GA}_{3} 0.01 \mathrm{mg} / \mathrm{l}$ agar gelgro $2 \mathrm{~g} / \mathrm{l} \mathrm{pH}$ 5.7. Perlakuan eksplan yang diuji adalah tanpa perlakuan pemanasan dan dengan perlakuan pemanasan. Eksplan digunakan di kedua perlakuan tersebut adalah 1/3 bulb/ umbi dan shoot tip/ jaringan meristematik dengan beberapa daun primordia.

Tahapan penelitian meliputi strilisasi bahan eksplan dan penanaman eksplan. Stelirisasi bahan eksplan dilakukan dengan cara bawang merah setelah perlakuan pemanasan atau tanpa perlakuan dikupas, diambil tunas umbi dan dikupas beberapa lapisan dari siung umbi bawang merah, dicuci dengan larutan deterjent dan bilas kembali dengan aquadest $2-3$ kali, lalu celupkan ke dalam alkohol 70\% dan rendam selama 15 menit di larutan clorox 25\%, bilas kembali dengan aquadest steril $3-5$ kali, dan dipindahkan ke cawan petri steril. Penanaman eksplan/ inokulasi dilakukan di lingkungan steril yaitu Laminer airflow cabinet (LAFC). Eksplan ditanam dalam tabung reaksi berukuran 50 x $150 \mathrm{~mm}$, yang berisi media MS+ MS vits + sukrose $30 \mathrm{~g} / 1+$ IAA $2 \mathrm{mg} / 1+$ Kinetin 2 $\mathrm{mg} / 1+\mathrm{GA}_{3} 0.01 \mathrm{mg} / 1$ + agar gelgro $2 \mathrm{~g} / 1$ pH 5.7 dengan volume $8-10 \mathrm{ml}$. Kultur diinkubasikan di ruang kultur dengan temperature $22-24{ }^{\circ} \mathrm{C}$, photoperiode 16 jam terang 8 jam gelap. Setiap perlakuan ditanam dalam 20 tabung reaksi. Pengamatan dilakukan secara visual pada 10 tabung reaksi yang diambil secara acak terhadap pertumbuhan dan perkembangan dari planlet.

\section{HASIL DAN PEMBAHASAN}

\section{Perlakuan pada Bawang merah cv. Pikatan}

Pada pengamatan persentase (\%) kontaminasi dan pertumbuhan dari eksplan, persentase eksplan yang terkontaminasi jamur atau bakteri umur 2 Minggu 
SetelahTanaman (MST) selalu lebih tinggi dari 4 MST dan 6 MST. Pertumbuhan eksplan $1 / 3$ bulb selalu lebih tinggi dari shoot tip.

Menurut Gunawan (1987) dan Armini dkk. (1992), sumber kontaminasi pada umumnya terbawa dari materi eksplan baik yang ada di permukaan atau di dalam eksplan (endogen). Kontaminasi juga dapat diakibatkan oleh teknik penanaman yang kurang baik, lingkungan di ruang kultur yang tidak memadai pada saat inkubasi. Dari semua sumber kontaminasi paling sulit diatasi adalah sumber kontaminan yang berasal dari dalam eksplan.

Berdasarkan Gambar 1 dan 2, persentase tumbuh dan berkembang untuk perlakuan eksplan 1/3 bulb atau shoot tip, semuanya 50\%. Pertumbuhan dan perkembangan eksplan di dalam kultur in vitro dipengaruhi oleh berbagai faktor yang sangat kompleks seperti faktor genetik, nutrisi: air, unsur makro, mikro serta sumber karbohidrat, faktor fisik: cahaya, suhu, $\mathrm{pH}$ media tumbuh, konsentrasi $\mathrm{O}_{2}$ dan $\mathrm{CO}_{2}$, serta asam organik, zat pengatur tumbuh, asam amino dan vitamin. Keberhasilan perbanyakan tanaman dengan teknik kultur jaringan dipengaruhi juga oleh respon kultivar (genotip), jenis eksplan, perlakuan pada eksplan dan komposisi media yang digunakan (George et al., 2008; Geier, 1990; Lee et al., 2009).

Pada Gambar 2, persentase abnormal asal eksplan shoot tip selalu lebih tinggi. Hal ini dimungkinkan dari asal eksplan yang telah diberi perlakuan pemanasan dan ukuran dari eksplan yang berpengaruh pada pertumbuhan dan perkembangan. Hal ini sesuai dengan pendapat Geier (1990) dan Teng (1997), menyatakan bahwa pemilihan eksplan dalam kultur jaringan berperan penting dalam keberhasilan dan pemilihan eksplan ini berkaitan erat dengan

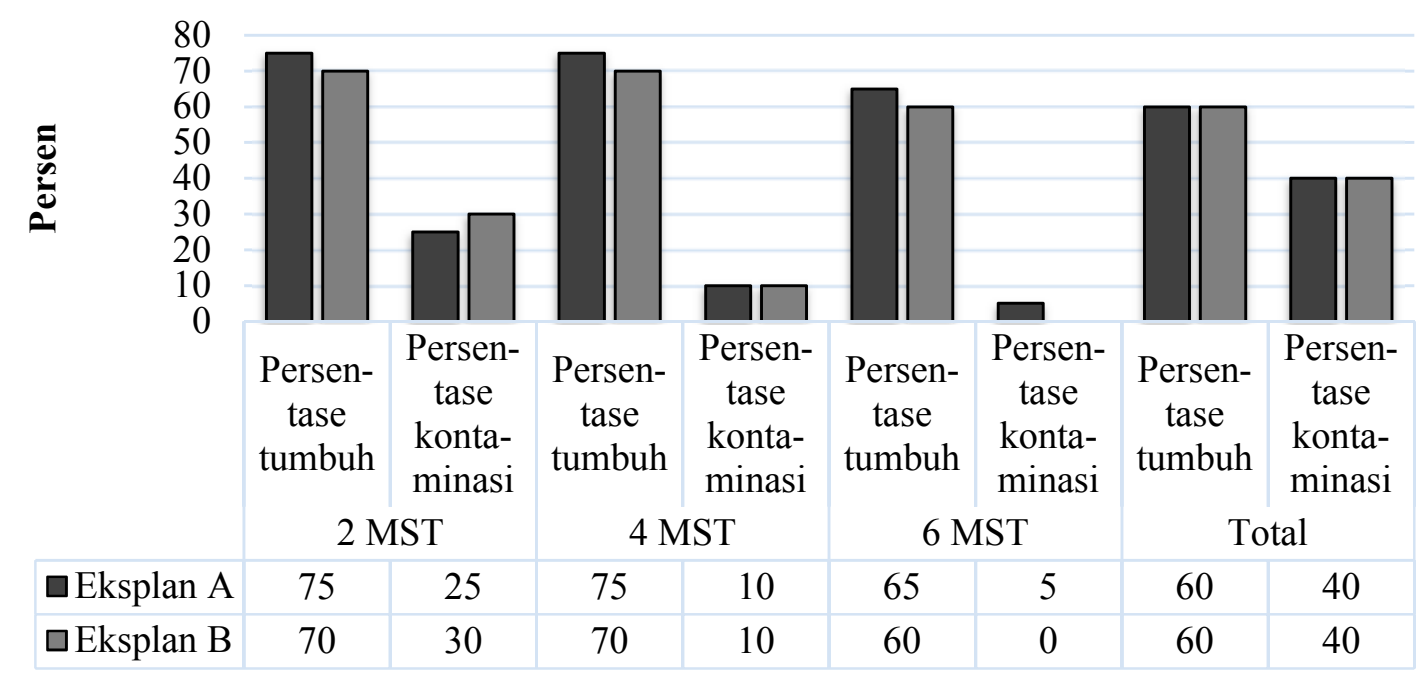

Gambar 1. Persentase eksplan bawang merah cv. Pikatan yang tumbuh dan terkontaminasi. Keterangan: eksplant $\mathrm{A}=1 / 3 \mathrm{umbi} /$ bulb; eksplan $\mathrm{B}=$ shoot tip; $\mathrm{MST}=$ minggu setelah tanam. 


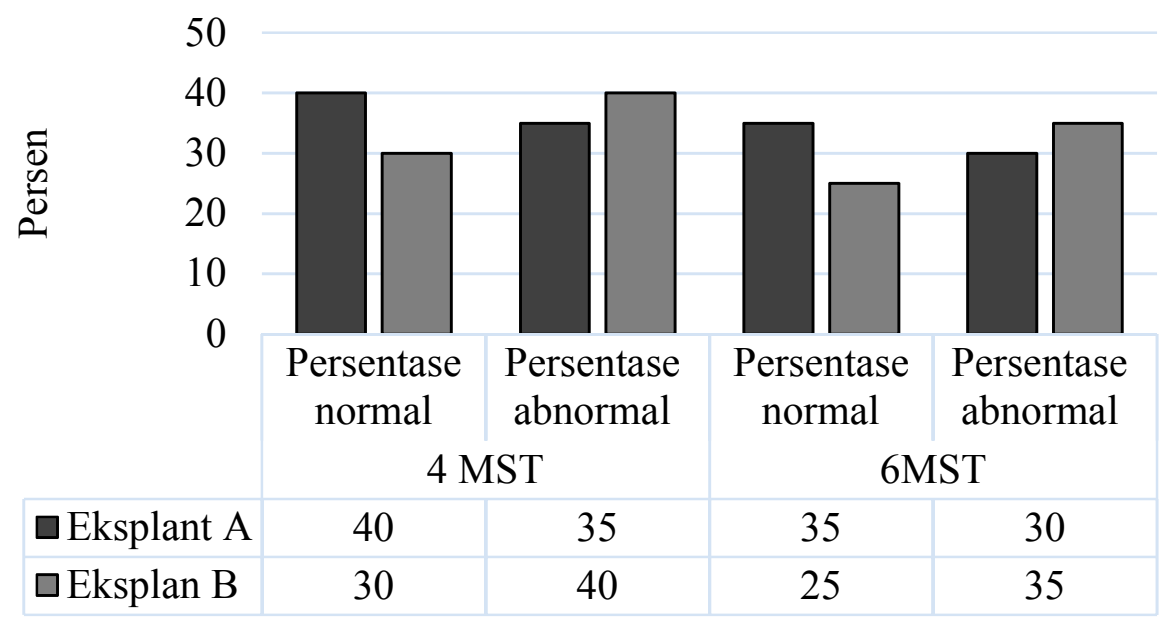

Gambar 2. Persentase pertumbuhan planlet normal dan abnormal. Keterangan: eksplan $\mathrm{A}=$ $1 / 3$ umbi $/$ bulb; eksplan $\mathrm{B}=$ shoot tip; $\mathrm{MST}=$ minggu setelah tanam.

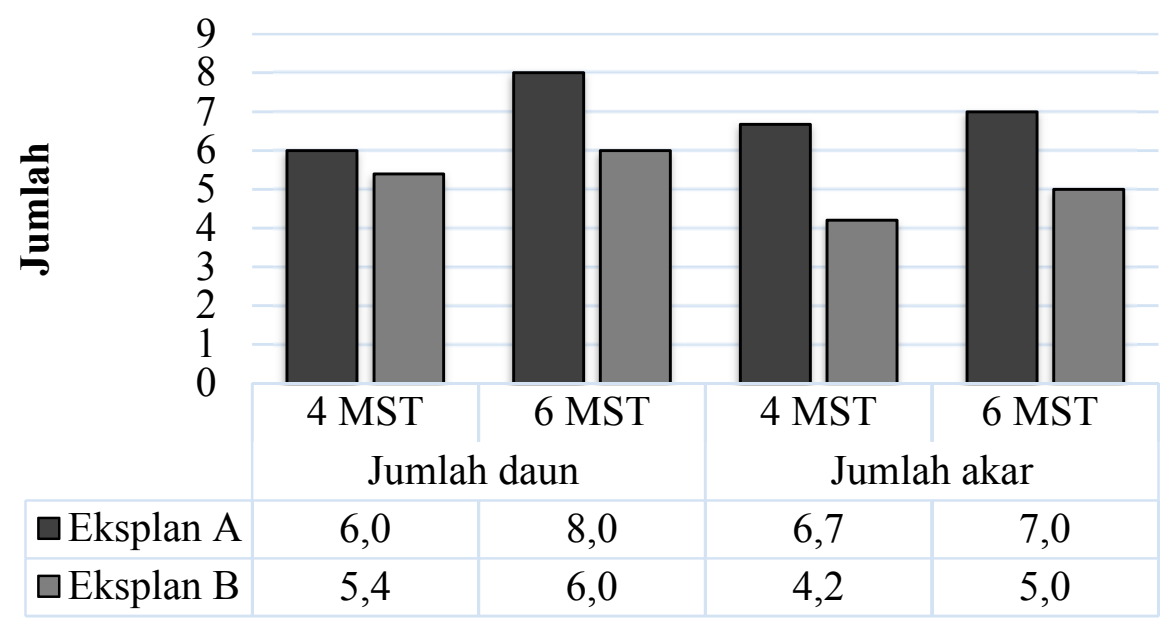

Gambar 3. Jumlah daun dan akar planlet bawang merah. Keterangan: eksplan $A=1 / 3$ umbi/bulb; eksplan B = shoot tip; MST = Minggu setelah tanam.

kemampuan regenerasi. Beberapa kasus menunjukkan bahwa laju tanaman hidup setelah perlakuan thermotheraphy makin kecil seiring dengan meningkatnya suhu pada perlakuan thermotheraphy (LozayaSaldam and Merlin - Lara, 1984; Gabriela et al., 2006).

Pengamatan jumlah daun dan akar menunjukkan semakin besar ukuran eksplan jumlah daun dan akar akan semakin besar pula (Gambar 3). Pada perbanyakan tanaman melalui kultur in vitro, respon dari eksplan bervariasi bergantung pada komponen kondisi kultur (komponen media tumbuh, unsur yang ditambahkan di media), jenis eksplan (kultivar, ukuran, asal eksplan). Seringkali kombinasi dari dua atau lebih komponen tersebut yang diaplikasikan secara stimultan maupun parsial diperlukan untuk meningkatkan respon dari eksplan. Menurut Welander (1985), Noiton et al. (1992) dan Kapoor et al. (2011), bahwa untuk meningkatkan pertumbuhan akar dari planlet dapat 
dilakukan dengan sub kultur eksplan pada media yang sama. Dengan sub kultur disamping mengubah eksplan yang sulit berakar menjadi lebih mudah berakar, tetapi juga menyebabkan terjadinya penurunan kemampuan regenerasi dan pertumbuhan planlet.

\section{Perlakuan Bawang merah cv. Bima Brebes.}

Hasil pengamatan persentase kontaminasi, persentase kultur yang terkontaminasi jamur atau bakteri umur 2 MST (Minggu SetelahTanam) selalu lebih tinggi dari pengamatan 4 MST dan 6 MST (Gambar 4). Disini dapat dikatakan sumber kontaminasi dapat berasal dari sumber planlet, baik dari perlakuan pemanasan atau tanpa pemanasan. Sterilisasi permukaan bahan eksplan belum mencukupi untuk menghilangkan sumber kontaminan di permukaan sumber eksplan.

Pada teknik kultur jaringan/kultur in vitro bahan eksplan yang terbebas dari sumber kontaminan merupakan langkah yang sangat penting. Kontaminan hidup dapat berupa jamur atau bakteri. Bila kontaminan tidak dihilangkan pada media tumbuh yang mengandung gula, vitamin, mineral, kontaminan terutama jamur dan bakteri akan tumbuh secara cepat. Explan yang tertutupi kontaminan akhirnya akan mati/tidak berkembang, sebagai akibat langsung dari serangan jamur, bakteri atau secara tidak langsung akibat persenyawaan toksik yang diproduksinya.

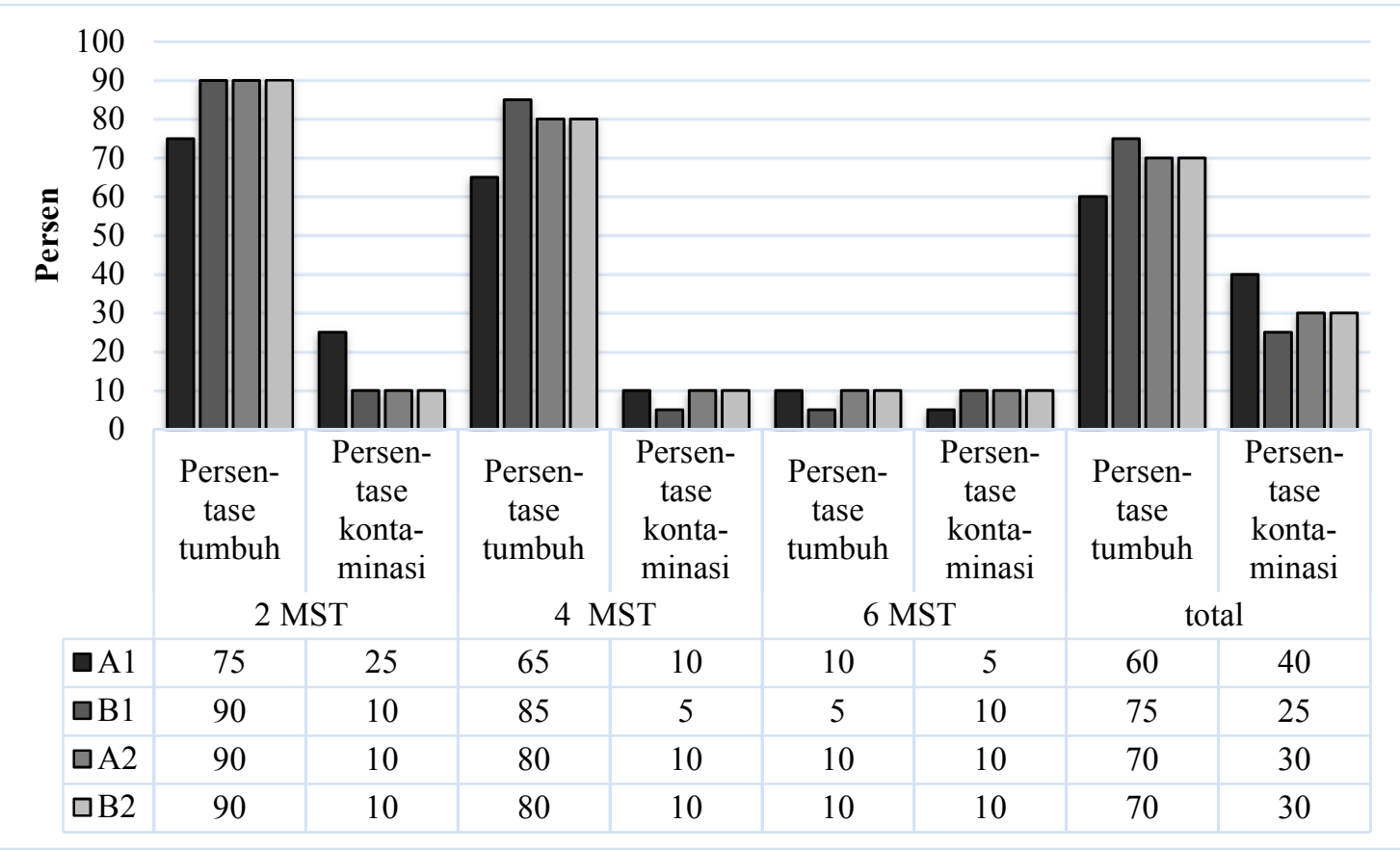

Gambar 4. Persentase eksplan bawang merah yang tumbuh dan terkontaminasi. Keterangan: eksplan $\mathrm{A}=1 / 3 \mathrm{umbi} /$ bulb; eksplan $\mathrm{B}=$ shoot tip; $\mathrm{MST}=$ minggu setelah tanam. 


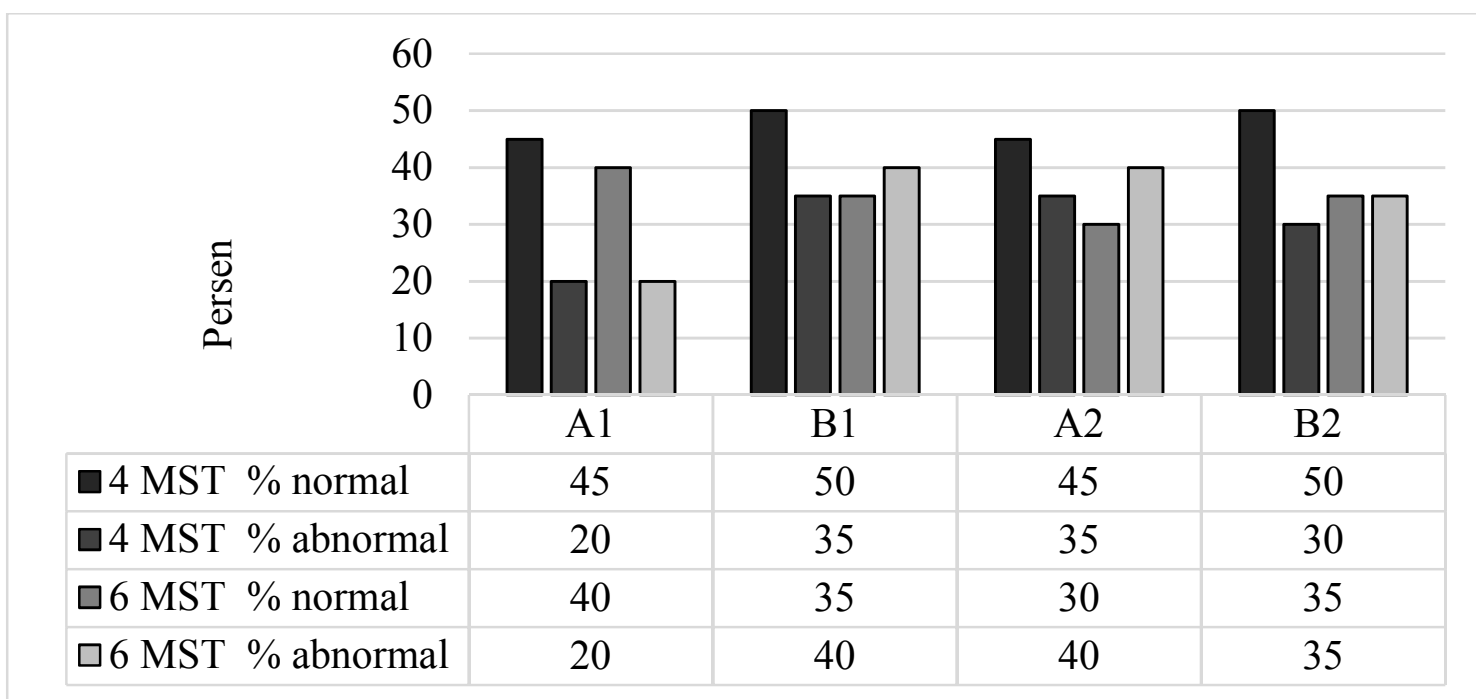

Gambar 5. Persentase planlet bawang merah tumbuh normal dan abnormal. Keterangan: eksplan A = 1/3 umbi/bulb; eksplan B = shoot tip; MST = Minggu setelah tanam

Pengamatan secara visual persentase tumbuh perlakuan eksplan shoot tip dan 1/3 bulb sampai dengan umur 2 MST tidak berbeda kecuali perlakuan $1 / 3$ bulb, tanpa pemanasan yang persentase kontaminasi tertinggi dari perlakuan lainnya. Menurut George dan Sherington (1984) Yanssen et al. (1994), perbanyakan tanaman secara in vitro memiliki banyak keuntungan diantaranya bahan tanaman yang diguakan lebih kecil sehingga tidak merusak pohon induk, lingkungan tumbuh dalam kultur in vitro aseptik dan terkendali, kecepatan perbanyakan tinggi, dapat menghasilkan benih bebas penyakit dari induk yang sudah mengandung patogen internal dan membutuhkan tempat yang relatif kecil untuk menghasilkan benih dalam jumlah besar.

Pada Gambar 5, persentase planlet tumbuh normal dan abnormal asal eksplan shoot tip persentase tumbuh normal selalu lebih tinggi kecuali pada $6 \mathrm{MST}$ perlakuan dengan pemanasan. Beberapa faktor utama yang menjadi kunci keberhasilan dalam kultur in vitro adalah sumber eksplan, media dasar dan ZPT, lingkungan fisik dan sistim regenerasi (Wattimena dkk., 2011; Dinarti dkk., 2008; Dugassa and Feyissa, 2011 ). Selain 4 faktor tersebut genotip tanaman juga mempengaruhi tingkat keberhasilan kultur in vitro. Umumnya setiap genotip dapat memberikan respon yang berbeda terhadap perlakuan eksplan dan formulasi media (Hoque and Mansfield, 2004; Luc and Bridgen, 1996). Penggunaan eksplan, media dasar, perlakuan asal eksplan, lingkungan tumbuh serta sistim regenerasi yang tepat diduga dapat meningkatkan daya multiplikasi tanaman.

Upaya mengeliminasi virus pada berbagai jenis tanaman telah berhasil dilakukan dengan menggunakan beberapa 
metode, seperti kultur meristem, terapi panas (thermoteraphy) dilanjutkan dengan perbanyakan melalui teknik kultur jaringan. Beberapa kasus menunjukkan bahwa laju tanaman hidup setelah perlakuan thermoteraphy makin kecil seiring dengan meningkatkanya suhu perlakuan asal eksplan saat thermotheraphy (LozayaSaldana and Merlin Lara, 1984; Tan et al., 2010).

Dua metode yang umum digunakan untuk memproduksi tanaman bebas penyakit virus adalah thermotheraphy dan kemoterapi dapat dilakukan secara tunggal atau dikombinasi dilanjutkan dengan teknik kultur jaringan atau kultur meristem (Awan et al., 2007; Fletche, et al., 1998; Gopal anf Garg, 2011; Ohta et al., 2011; Sedlak et al., 2011). Tanaman bebas virus dapat diartikan virus tertentu terdeteksi negatif ditanaman. Kombinasi spesifik temperatur, bahan kimia, dan metode kultur in vitro untuk menghasilkan tanaman bebas virus ditentukan oleh sensitivitas virus dan perlakuan tanaman. Perlakuan pemanasan materi eksplan efektif untuk menonaktifkan virus, tetapi mungkin untuk tanaman bawang merah cv. Trisula dan cv, Bima Brebes tidak sesuai / tidak cocok, jika tanaman bawang ini sensitif terhadap panas. Tujuan perlakuan pemanasan adalah untuk menonaktifkan perkembangan virus tetapi tidak mematikann tanaman.

Kelompok virus yang umum menyerang bawang-bawangan berasal dari Carla virus, Potty virus dan Allexi virus. Virus utama pada tanaman bawang merah diantaranya SLV (Shallots Latent Virus), OYDV (Onions Yellow Dwarf Virus), SYSV (Shallots Yellow Strips Virus) dan LYSV (Leeks Yellow Strips Virus) (Diekmann, 1997). Hasil penelitian Gunaeni dkk. (2011), di Indonesia dengan metode $D A S$ ELISA terdeteksi 3 jenis virus $O Y D V$, SYSV dan $L Y S V$. Infeksi campuran beberap virus merupakan fenomena yang sering ditemukan pada penyakit yang disebabkan oleh virus.

Tabel 1. Hasil deteksi virus pada kultur planlet Bawang merah cv. Bima Brebes

\begin{tabular}{|c|c|c|}
\hline Perlak & $\begin{array}{l}\text { Jumlah } \\
\text { kultur }\end{array}$ & Jumlah kultur terinfeksi \\
\hline
\end{tabular}

Tanpa Pemanasan

\begin{tabular}{llllll} 
A1 $(1 / 3$ bulb) & 8 & 5 & 3 & 8 & $8 / 8(100,00)$ \\
B1 (shoot tip) & 7 & 4 & 2 & 6 & $6 / 8(75,00)$ \\
\hline $\begin{array}{llll}\text { Dengan Penamasan } \\
\text { A2 (1/3 bulb) }\end{array}$ & 6 & 3 & 2 & 5 & $5 / 6(83,33)$ \\
B2 (shoot tip) & 7 & 3 & 3 & 6 & $6 / 7(85,71)$ \\
\hline
\end{tabular}

Keterangan: $O Y D V=$ Onion Yellow Dwarf Virus; SYSV = Shallot Yellow Stripe Virus. 
Pada tabel 1, hasil uji virus dengan serologi DAS ELISA, persentase planlet terinfeksi masih tinggi. Menurut Zaitlin and Palukautis (2000), virus masih terdeteksi hal ini mengindeikasikan bahwa perlakuan pemanasan pada bahan eksplan bawang merah cv, Bima Brebes belum optimal untuk mengeliminasi virus. Sehingga saat eksplan ditanam pada media secara in vitro di media regenerasi pertikel virus masih terbawa.

Thermotheraphy atau perlakuan pemanasan dilakukan untuk menghilangkan penyakit virus dan virus virus lainnya yang menunjukkan penurunan laju multiplikasi pada suhu tinggi. Metode ini berhasil diterapkan di beberapa tanaman di kisaran $35-40{ }^{\circ} \mathrm{C}$ (Sharma et al., 2007). Tingkat toleransi dan tingkat kelangsungan hidup dari tanaman dengan meningkatnya suhu pemanasan juga menjadi faktor pembatas dalam perlakuan pemanasan (LozayaSaldana dan Merlin Lara, 1984; Torress et al., 2000)

\section{KESIMPULAN}

1. Perlakuan pemanasan bahan eksplan bawang merah cv. Bima Brebes dan cv. Pikatan, belum menurunkan pesentase planlet yang terinfeksi virus.

2. Pertumbuhan eksplan asal $1 / 3$ bulb maupun shoot tip, masing-masing di atas 50\%. Umumnya semakin kecil eksplan, persentase planlet abnormal semakin tinggi.

3. Kontaminasi kultur cv. Bima Brebes maupun Pikatan umumnya disebabkan bakteri dan jamur yang terbawa dari eksplan (endogen).

4. Perlakuan pemanasan bahan eksplan bawang merah secara visual tidak berpengaruh pada persentase pertumbuhan dan pesentase kultur terkontaminasi.

\section{UCAPAN TERIMA KASIH}

Penelitian ini dibiayai oleh ACIAR Project - Hort 2009 - 056. Sustainable productivity improvements in Allium and Solanaceous Vegetable Crops in Indonesia and Sub Tropical Australia. Terima kasih juga kami sampaikan kepada Dr Witono Adiyoga, MS sebagai ketua tim dalam project ini.

\section{DAFTAR PUSTAKA}

Abo -El Nil, M.M. 1977. Organogenesis and embryogenesis in callus culture of garlic (Allium sativum L). Plant Sci. Letter 9(3): 259 - 264.

Armini, G.A. Wattimena, dan L. Winata. 1992. Perbanyakan tanaman dalam bioteknologi tanaman I. pp 12- 18. In. Wattimena (ed). PAU Bioteknologi IPB. Dirjen Dikti. Dept. P\& K ,

Awan, A.R. S.M. Mughal, Y. Iftilhar and H.Z Khan. 2007. In vitro elimination of potato leaf roll virus from potato varieties. Euro. J. Res. 18; 154- 164. 
Ayabe, M, and S. Sumi. 1988. Establishment of novel tissue culture method, stem disc culture and its practical application to micro propagation of garlic (Allium sativum L). Plant cell culture Rept., 17(10): $773-779$.

Buitteveld, J and C. Molenaarm. 1994. Plant regeneration from protoplast isolated from suspension culture of leek (Allium ampeoprasum L). Plant Sci., 100(1): $2003-2010$.

Diekmann, M. 1997. Technical guide lines for the safe movement of germplasm No. 18. Alliums Spp. Rome (IT), Food and Agric Org. of UN. Rome. Int. Plant genetic Resource Inst. Rome.

Dinarti, D, A. Purwito, A.D. Susila, dan I. Rahmawati. 2008. Pembentukan umbi lapis mikro dua kultivar bawang merah (Allium cepa var. aggregatum group) pada beberapa konsentrasi succinic acid Daminozide Hydrazide. J. Ilmu Pertanian Ind., 13(1): 32 - 37.

Dugassa, G. and T. Feyissa. 2011. In vitro production of virus free sweet potato (Ipomoe batatas L.) by meristem culture and thermotheraphy. Etiop. $J$. Sci., 34(1); 17 - 28

Eady C, R.C. Bulter and Y. Suo. 1998. Somatic embryogenesis and plant regeneration from immature embryo culture of onion (Allium cepa L.) . Plant Cell. Report., 18(1-2): 111 116.

Fletcher P.J, J.D. Fletcher and S.L. Lewthwaite. 1998. In vitro elimination of onion yellow dwarf and shallot latent viruses in shallots (Allium cepa var ascolonicum L.). New Zealand J. Crop. Hort. Sci., 26(1): $23-26$.

Gabriela F.L., A.K. May, C. Pellegrini, and F.L. Curvetto. 2006. Effects of explants and growth regulators in garlic callus formation and plant regeneration. Plant Cell. Tiss. Organ Cult., 87(2): 139-143.

Geier, T. 1990. Anthurium. Pp. 228 - 252. In Ammirato P.V; D.A. Evans; W.R Sharp and Y.P.S. Bajaj (eds). Handbook of Plant Cell Culture Ornamental Species. Mac. Grow Hill. New York.

George, E.F; M.A. Hall, and G.J. De Klerk. 2008. The component of plant tissue culture medium I, macro and micro nutrient's. pp. 274 -338. In: George, E.F; M.A. Hall, and G.J. De Klerk (Eds). Plant propagation by tissue culture, the background vol I $3 \mathrm{rd}$ Edition. Springer Netherlands.

George, E.F and P. D. Sherington 1984. Plant propagation by tissue culture. Exegetic. Ltd. England.p.184-223

Gopal, J and I.D. Garg. 2011. An efficient protocol of chemo-thermotherapy for elimination of potato (Solanum tuberosum ) viruses by meristem -tip culture. Ind Agr. Sci., 81(6):544 -549.

Gunaeni,N., A.W. Wulandari dan A. Muharam. 2011. Insiden penyakit tular umbi pada tiga belas varietas bawang merah asal Jabar dan Jateng. J. Hort. 21 (2): 164 - 172.

Gunawan, L. W. 1988. Teknik kultur tumbuhan. PAU. IPB. Bogor, 252p.

Hoque, M.E and J.W. Mansfield. 2004. Effect of genotype and explants age on callus induction and subsequent plant regeneration from root- derived callus of indica rice genotypes. Plant cell Tissue. Org. cult., 78(3): 217 223.

Kamstaityte, D. and S. Stanys. 2004. Micropropagation of onion (Allium cepa L). Latv. Biol., 676: 173 - 176.

Kapoor, R., S.A. Nasrin, Mahmooduzzafar and A. Mujib. 2011. Establishment of efficient method for callus culture and shoot regeneration of local Indian 
garlic (var. Yamum safed). J.of Ecobio technology, 3(12): 14 - 17.

Kurniawan, A dan G. Suastika. 2013, Deteksi dan identifikasi virus pada umbi bawang merah (Detection and identification of plant viruses on shallot). J. Fitopatologi. 9(2): 47 - 52.

Lee S.Y., .H.H. Kim, Y.K. Kim,N.I. Park and S.U. Park. 2009. Plant regeneration of garlic (Allium sativum L) via somatic embryogenesis. Sci. Res. And Essay., 4 (13): 1569 - 1574.

Lozaya-Saldana, H. and O. Merlin Lara. 1984. Thermotheraphy and tissue culture for elimination of potato virus $\mathrm{x}(\mathrm{PVX})$ in Mexican potato cultivars resistant to late blight. Am. Pot. J., 61(12): $737-739$.

Luc and M.P.Bridgen. 1996. Effects of genotype culture medium and embryo developmental stage on the in vitro responses from ovules cultures interspesific hybrids of Alstroemeria. Plant Sci., 116(2): 205 - 212.

Noiton, D, J.H. Vine and M.G. Mullins. 1992. Effect of serial sub culture in vitro on the endogenous levels of indole-3-acetic acid and abscisic acid and root ability in micro cutting of "Jonathan" Apple. Plant growth regulation, 11(1): 337 - 383 .

Ohta S, T. Kuniga, F. Nishikawa, A. Yamasaki, T. Endo, T. Iwanani and T. Yoshida. 2011. Evaluation of novel antiviral agents in the elimination of Satsuma Dwarf virus (SDV) by semi micrografting in citrus. J. Japan Soc. Hort. Sci., 80(2): 145 - 149.

Sedlak J, F. Paprstein and L. Talacko. 2011. Elimination of Apple stem pitting virus from pear cultivars by in vitro chemotheraphy. Acta Hort., 923:111- 115 .

Seif EL-Nasr, H., Gadel-Hak, Z.A.Kasem, Yasser, M.M. Moustafa and A.S. Ezzat. 2011. Growth and cytogenetical properties of micro- propagated and successfully acclimatized garlic (Allium sativum L.) clones with a modified shoot tip culture protocol. J. Hort. SCi and Ornament Plants, 3(2): 115 - 129.

Sharma S, S.B. Singh, G. Rani, A.A. Zaidi, V. Hallan, A. Nagpal and G.S. Virk. 2007. Production of Indians citrus ringspot virus free plants of kinnow employing chemotheraphy coupled with shoot tip grafting. J. Cent. Eur. Agric., 8(1): 1 - 8 .

Tan, R, L. Wang, Hong Ni, and W. Guoping. 2010. Enhanced efficiency of virus eradication following thermotherapy of shoot - tip cultures of pear. Plant Cell. Tissue Org. Cult., 101: $229-235$.

Teng, W.L. 1997. Regeneration of Anthurium Adventitious shoots using liquids or raft culture. Plant. Cell Tissue and Organ Cult., 49(2): 153 156.

Torres, A.C, T.V. Fajardo, A.N. Dusi, R.O. Resende, and J.A. Buso. 2000. Shoot tip culture and Thermotheraphy in recovering virus free plants of garlic. Horticulture Brasifeire Brasilia, 18(3): 192 -195.

Walkey, D.G.A, M.J.W. Webb, C.J. Bold and A. Miller. 1987. Production of virus free garlic (Allium sativum L.) and Shallots (Allium ascolonicum L.) by meristem tip culture. J, Hort. Sci., 62(2):211 - 219 .

Wattimena, G.A., M. Nurhayati, N.M. Armini, A. Purwito, D. Efendi, B.S. Purwoko dan N. Khumaida. 2011. Bioteknologi dalam Pemuliaan Tanaman. IPB Press, Bogor.

Welander M, 1985. In vitro shoot and root formation in apple cultivars Akero. Annals Botany, 55(2): 249 - 261.

Yasseen, Y.M, W.E. Splittstoesser, and R.E. Litz. 1994. In vitro shoot proliferation and production of sets 
from garlic and shallot. Plant cell. Tiss. Org., 36(2): 243-247.

Zailin M. and P. Pakukaitis. 2000. Advances in understading plant viruses and virus diseases. Am. Dev. Phytophatol, 38: 117 - 143.
Zheng, S., B. Henken, E. Sofiari, E. Jacobsen, F.A. Krens, and C. Kik. 1998. Factors influencing induction propagation and regeneration of mature zygotic embryo derived callus from Allium cepa. Plant Cell. Tissue and Organ Culture, 53(2): 99 - 105. 